ISSN : 2615-1995, E-ISSN : 2615-0654

J. Madani., Vol. 1, No. 2, September 2018 (399-415)

C2018 Lembaga Kajian Demokrasi

MADANI

dan Pemberdayaan Masyarakat (LKD-PM)

\title{
PENGARUH PROMOSI DAN PRODUK TERHADAP MINAT BELI (PADA PT. ASURANSI JIWA RECAPITAL DI JAKARTA)
}

\author{
Fauziah Septiani \\ Fakultas Ekonomi, Universitas Pamulang \\ fauziahseptiani0209@gmail.com
}

\begin{abstract}
Abstrak
Penelitian ini bertujuan untuk mengetahui pengaruh promosi dan produk terhadap minat beli pada PT. Asuransi Jiwa Recapital di Jakarta. Metode yang digunakan adalah explanatory research, dan pengujian hipotesis. Dengan teknik survei, menyebar kuesioner dengan skala Likert. Teknik penentuan memakai sampling jenuh dengan 100 responden. Teknik analisis data yang digunakan analisis deskriptif dan analisis statistik inferesial yaitu: 1.Uji Validitas dan Reliabilitas, 2. Uji Asumsi Klasik, 3.Analisis Regresi Berganda, 4.Analisis Koefisien Korelasi, 5.Analisis Koefisien Determinasi $\left(R^{2}\right)$, 6. Pengujian Hipotesis dengan Uji Parsial (uji t) dan Uji Simultan (uji F). Hasil Pengujian dan analisisnya adalah sebagai berikut:

1. Terdapat pengaruh positif dan signifikan antara promosi terhadap minat beli, dengan korelasi positif 0464 dan kontribusi pengaruh sebesar 21,5\%. Uji hipotesis diperoleh nilai $t_{\text {hitung }}$ sebesar 5,182 dengan signifikansi t sebesar 0,000 .

2. Terdapat pengaruh positif dan signifikan antara produk terhadap minat beli, dengan korelasi positif 0,438 dan kontribusi pengaruh sebesar 23,6\%. Uji hipotesis diperoleh nilai $t_{\text {hitung }}$ sebesar 5,405 dengan signifikansi t sebesar 0,000 .

3. Terdapat pengaruh positif dan signifikan antara promosi dan produk secara simultan terhadap minat beli dengan korelasi positif 0,601 dan mempunyai kontribusi pengaruh sebesar 36,1\% dan sisanya sebesar 63,9\% dipengaruhi faktor lain yang tidak diteliti. Uji hipotesis diperoleh nilai $F_{\text {hitung }}$ sebesar 27,400 dengan signifikan $F$ sebesar 0,000.
\end{abstract}

Kata Kunci : Promosi, Produk, Minat Beli

\section{PENDAHULUAN}

\section{Latar Belakang}

Melihat perkembangan zaman yang semakin maju, persaingan dalam dunia bisnis atau industri seperti persaingan di dalam dunia bisnis yang menyebabkan kegiatan manufaktur dan non manufaktur (jasa) sangat membutuhkan kemampuan baru agar perusahaan dapat berhasil secara kompetitif untuk sebuah perusahaan memenuhi sebuah kebutuhan konsumen.

Mengembangkan Asuransi saat ini masih sedikit dipandang sebelah mata oleh ma- syarakat, hal seperti ini dikarenakan masih banyak masyarakat yang belum sadar akan pentingnya asuransi di masa sekarang serta masa yang akan dating. Saat ini Perusahaan yang bergerak dibidang jasa asuransi sedang berusaha keras memperkenalkan produkproduk asuransi kepada masyarakat agar bisa tertarik dan sadar dengan pentingnya asuransi.

Produk jasa terkemuka dalam asuransi adalah asuransi jiwa, dimana produk tersebut merupakan salah satu yang paling penting untuk meminimalkan resiko yang mungkin akan terjadi dalam kehidupan. Dalam hal ini 
khusus resiko yang bersifat financial dan dapat membahayakan kesejahteraan keluarga akibat terjadi musibah seperti sakit, kecelakaan serta kematian.

Metode perlindungan yang diberikan oleh perusahaan asuransi sangatlah dibutuhkan, dalam dunia bisnis yang penuh dengan resiko dimana secara rasional para pebisnis pasti akan mempertimbangkan usahanya untuk mengurangi resiko yang dihadapi. Ada beberapa faktor yang mempengaruhi dan menentukan tercapainya tujuan perusahaan salah satunya adalah promosi. Promosi juga dianggap sebagai komponen yang paling mempengaruhi supaya tercipta kepercayaan konsumen untuk sadar akan asuransi.

Pada masalah ini kita bisa lihat bahwa perusahaan yang bergerak di bidang jasa asuransi diatur dalam undang-undang Nomor 2 Tahun 1992, Pasal 1 bahwa asuransi adalah Perjanjian antara dua pihak atau lebih, dengan nama pihak tertanggung mengikatkan diri kepada tertanggung dengan menerima premi asuransi, untuk memberikan penggantian kepada tertanggung karena kerugian, kerusakan atau kehilangan keuntungan yang diharapkan atau tanggung jawab hukum kepada pihak ketiga yang mungkin akan diderita tertanggung, yang timbul dari suatu peristiwa tidak pasti atau untuk memberikan suatu pembayaran yang didasarkan atas meninggal atau hidupnya seseorang yang dipertanggungkan.

Pada Saat ini kita lihat di Indonesia semakin banyak perusahaan asuransi yang berlomba untuk mempromosikan dan memperkenalkan produk asuransinya kepada masyarakat. Pada moment ini perusahaan asuransi harus bisa bersaing dengan perusahaan-perusahaan lain yang bergerak dibidang asuransi juga, yang harus lebih diperhatikan adalah bagaimana cara memenuhi kebutuhan konsumen saat ini, yang harus diperhatikan adalah promosi yang lebih kreatif untuk menarik minat konsumen dan produk-produk yang dijual juga harus dilihat dari kebutuhan konsumen.

Masyarakat saat ini sudah mulai paham dan sadar apa itu asuransi serta betapa pentingnya asuransi, hal ini juga mendorong untuk bangkitnya perusahaan asuransi karena bisnis asuransi ini juga suatu hal yang menjanjikan. Sudah banyak perusahaan-perusahaan asuransi yang terlihat berlomba untuk mempromosikan produknya. Semakin banyaknya pesaing dalam bisnis asuransi, para pebisnis tidak berhenti untuk menciptakan lagi sebuah produk yang bisa dinikmati oleh masyarakat luas, perusahaan dan instansi-instansi lainnya. Keberhasilan suatu produk juga salah satunya dengan melalui pemanfaatan alat promosi yang efektif.

Menurut Philip Kotler dan Gary Amstrong (2012:173) Promosi merupakan sebuah aktifitas komunikasi yang bertujuan untuk memperlancar arus produk, servis atau ide tertentu pada sebuah aliran distribusi. Hal ini merupakan sebuah usaha untuk membujuk calon konsumen untuk menerima, membeli, merekomendasikan atau menggunakan produk yang sedang dipromosikan. Secara singkat bisa dikatakan bahwa promosi suatu usaha untuk mempengaruhi sikap atau perilaku yang menerima untuk membujuk mereka agar menerima konsep yang ditawarkan.

Upaya yang dilakukan dalam memasarkan suatu produk dengan melakukan promosi yang meliputi advertising, sales promotion, personal selling, public relation, direct marketing supaya calon konsumen lebih memahami produk yang ditawarkan. Sebelum melakukan promosi perusahaan harus membentuk ide yang tepat dan terpadu dan mencakup bauran promosi seperti iklan, penjualan tatap muka, penjualan mulut ke mulut atau dalam bentuk publisitas seperti seminar agar menghasilkan komunikasi yang baik misal harus bisa menceritakan kelebihan produk dan bisa membujuk para calon konsumen agar membeli produk yang kita tawarkan.

Adapun promosi yang telah di lakukan oleh PT Asuransi Jiwa Recapital, promosi masih sangat kurang dikalangan masyarakat umum, promosi penjualan yang pelaksanaannya di lakukan sesuai dengan kondisi konsumen sebagai pengguna jasa. Beberapa strategi yang digunakan oleh PT Asuransi Jiwa Recapital untuk mendapatkan pelanggan dikatakan kurang berhasil karena pelanggan yang percaya terhadap produk-produk yang ditawarkan belum sepenuhnya di terima oleh pelangan dalam hal ini mempengaruhi jumlah pelanggan khususnya di Kota Jakarta.

Selain Promosi Perusahaan harus memperhatikan produk yang akan dijual kepada konsumen sesuai dengan permintaan konsumen. Perusahaan ini mempunyai beberapa produk 
asuransi jiwa (kesehatan) seperti rawat jalan, rawat inap, persalinan, imunisasi, perawatan gigi dan pemeriksaan mata, dan lain-lain. Hal ini selaras dengan pendapat Kotler\&Amstrong (2001:346) di mana produk adalah segala sesuatu yang dapat ditawarkan kepasar untuk mendapatkan perhatian, dibeli, digunakan atau dikonsumsi yang dapat memuaskan keinginan atau kebutuhan. Atau bisa kita tarik kesimpulan bahwa produk adalah pemahaman dari produsen atas sesuatu yang bisa ditawarkan sebagai ide atau usaha dalam mencapai tujuan organisasi melalui pemenuhan kebutuhan kegiatan konsumen selaras dengan kapasitas daya beli pasar.

Semakin meningkatnya persaingan bisnis asuransi bisa meningkatkan minat beli yang diinginkan oleh konsumen hal ini selaras dengan pendapat Kottler\&Keller (2003:181) bahwa minat beli konsumen adalah sebuah perilaku konsumen dimana konsumen mempunyai keinginan dalam membeli atau memilih suatu produk, berdasarkan pengalaman dalam memilih, mengunakan dan mengkonsumsi atau bahkan menginginkan suatu produk. Perusahaan harus berupaya agar produknya menarik minat beli masyarakat.

Mengingat bahwa promosi dan produk merupakan salah satu faktor penting yang dapat meningkatkan minat beli, maka penulis tertarik untuk melakukan penelitian lebih dalam dengan judul "Pengaruh Promosi dan Produk Terhadap Minat Beli Pada PT. Asuransi Jiwa Recapital di Jakarta”.

\section{Pembatasan Masalah}

Dengan keterbatasan peneliti serta agar lebih mudah di pahami dan dimengerti maka penelitian ini penulis memberikan batasanbatasan yang diteliti, yaitu mengenai promosi dan produk dan pengaruhnya terhadap minat beli pada PT. Asuransi Jiwa Recapital, dengan cara melakukan penyebaran kuesioner kepada pelanggan.

\section{Perumusan Masalah}

Berdasarkan identifikasi dan pembatasan masalah di atas, maka untuk mencegah terjadinya kerancuan dalam pembahasan, perlu penulis berikan suatu perumusan masalah sebagai berikut :

1. Bagaimana pengaruh secara parsial antara promosi terhadap minat beli pada PT. Asuransi Jiwa Recapital di Jakarta?

2. Bagaimana pengaruh secara parsial antara produk terhadap minat beli pada PT. Asuransi Jiwa Recapital di Jakarta?

3. Bagaimana pengaruh secara simultan antara promosi dan produk terhadap minat beli pada PT. Asuransi Jiwa Recapital di Jakarta?

\section{Tujuan Penelitian}

Tujuan penelitian ini adalah :

1. Untuk mengetahui seberapa besar pengaruh secara parsial antara promosi terhadap minat beli pada PT. Asuransi Jiwa Recapital di Jakarta .

2. Untuk mengetahui seberapa besar pengaruh secara parsial antara produk terhadap minat beli pada PT. Asuransi Jiwa Recapital di Jakarta.

3. Untuk mengetahui seberapa besar pengaruh secara simultan antara promosi dan produk terhadap minat beli pada PT. Asuransi Jiwa Recapital di Jakarta.

\section{Tinjauan Teoritik}

\section{Manajemen}

Pengertian manajemen banyak disampaikan oleh beberapa ahli. Manajemen berasal dari kata to manage yang mengandung arti mengatur. Dalam hal ini pengaturan dilakukan dalam pproses tertentu berdasarkan fungsi manajemen itu sendiri. Sedangkan menurut Sudjana (2007) berpendapat bahwa "Manajemen merupakan rangkaian berbagai kegiatan wajar yang dilakukan seseorang berdasarkan norma-norma yang telah ditetapkan dan dalam pelaksanaannya memiliki hubungan dan saling keterkaitan dengan lainnya". Lain halnya dengan pendapat Hasibuan (2014) yang mendefinisikan "Manajemen adalah ilmu dan seni mengatur proses pemanfaatan sumber daya manusia dan sumber-sumber lainnya secara efektif dan efisien untuk mencapai suatu tujuan tertentu".

Dari beberapa pendapat di atas, maka daisimpulkan bahwa manajemen merupakan suatu proses atau kegiatan mulai dari planning, organizing, actualing, controlling (POAC) untuk mencapai tujuan yang telah ditetapkan sebelumnya secara efektif dan efisien. 


\section{Manajemen Pemasaran}

Seperti yang telah diketahui bahwa manajemen pemasaran memiliki peran yang sangat penting didalam sebuah perusahaan maupun organisasi. Salah satu aspek yang ada didalamnya adalah merencanakan suatu produk baru dan memilih pangsa pasar yang sesuai dengan kondisi suatu produk tertentu serta memperkenalkan produk baru kepada pelanggan luas. Pengertian manajemen pemasaran menurut Kotler dan Keller (2016) adalah "Manajemen Pemasaran sebagai seni dan ilmu untuk memilih pasar sasaran dan meraih, mempertahankan, serta menumbuhkan pelanggan dengan menciptakan, menghantarkan, dan mengkomunikasikan nilai pelanggan yang unggul. Lain halnya dengan pendapat Manap (2016) yang menyampaikan bahwa "Manajemen Pemasaran merupakan suatu proses untuk meningkatkan efisiensi dan efektivitas dari kegiatan pemasaran yang dilakukan oleh individu atau oleh perusahaan.

Dari beberapa definisi diatas, dapat disimpulkan bahwa manajemen pemasaran merupakan rangkaian proses untuk menciptakan suatu nilai guna membantu pencapaian tujuan organisasi atau perusahaan. Kegiatan pemasaran itu dilakukan melalui serangkaian proses perencanaan, pengarahan, pengendalian, dan penetapan harga, pemetaan distribusi, serta kegiatan promosi.

\section{Pemasaran}

Setiap perusahaan pasti akan menganut salah satu konsep atau filosofi dalam usaha pemasarannya. Perumusan tersebut dimaksudkan agar dalam setiap kegiatannya dapat terarah dan tergorganisir dengan baik sehingga dapat menghasilkan perkembangan yang lebih baik dari sebelumnya.

Menurut Kotler (2014) mendefinisikan bahwa "Pemasaran diartikan sebagai suatu proses dimana perusahaan menciptakan nilai bagi pelanggan dan membangun hubungan yang kuat dengan pelanggan dengan tujuan menangkap nilai dari pelanggan sebagai imbalannya”.

Sedangkan menurut William J. Stanton \& Charles Futrell dalam Bashu Swasta (2012) mendefinisikan bahwa "Pemasaran merupakan system keseluruhan dari adanya kegiatan yang bertujuan untuk merencanakan, menentukan harga serta mendistribusikan barang atau jasa serta ide kepada pasar sasaran yang dituju sehingga dapat mencapai tujuan organisasi dengan baik".

Dari beberapa definisi tersebut di atas, maka disimpulkan bahwa pemasaran adalah suatu proses kegiatan untuk berinteraksi antara individu dan kelompok untuk memperoleh apa yang mereka butuhkan dan mereka inginkan dengan menciptakan atau menawarkan produk dan jasa kepada pelanggan.

\section{Promosi}

Yang dimaksud promosi dalam penelitian ini adalah kegiatan komunikasi perusahaan dalam usaha memperkenalkan suatu produk jasanya kepada pelanggan dengan harapan pelanggan mengetahui adanya produk yang duhasilkan. Menurut Kotler dan Keller (2014) berpendapat bahwa "Promosi adalah ramuan khusus dari iklan pribadi, promosi penjualan dan hubungan masyarakat yang digunakan perusahaan untuk mencapai tujuan iklan dan pemasarannya". Adapun indikator yang dipakai adalah periklanan (advertising), promosi penjualan (sales promotion), penjualan pribadi (personal selling), dan publisitas (publication).

\section{Produk}

Yang dimaksud produk dalam penelitian ini adalah jenis produk jasa dengan kualitas keunggulannya yang ditawarkan kepada pelanggan. Menurut Fandy Tjiptono dan Gregorius Chandra (2011) berpendapat bahwa "Produk mencerminkan semua dimensi penawaran produk yang menghasilkan manfaat (benefits) bagi pelanggan. Kualitas suatu produk baik berupa barang atau jasa ditentukan melalui dimensinya". Adapun indikator yang dipakai dalam penelitian ini adalah : kinerja (performance), daya tahan (durability), kesesuaian dengan spesifikasi (conformance to specifications), fitur (features), reliabilitas (reliability), estetika (aesthetics), kesan kualitas (perceived quality), dan kecepatan dan kemudahan (serviceability).

\section{Minat Beli}

Yang dimaksud minat beli dalam penelitian ini adalah keinginan dari pelanggan untuk melakukan pembelian atas produk yang dihasilkan oleh perusahaan sebagai akibat 
dari adanya rangsangan (stimulus) yang ditawarkan oleh perusahaan dimana masingmasing stimulus tersebut dirancang untuk menghasilkan tindakan pembelian konsumen. Adapun indikator yang dipakai adalah minat transaksional, minat refrensial, minat preferensial dan minta eksploratif.

Menurut Ferdinand (2012) berpendapat "Minat beli merupakan perilaku konsumen yang menunjukkan sejauh mana komitmennya untuk melakukan pembelian sesuai dengan kebutuhan dan keinginannya". Adapun indikator yang dipakai adalah minat transaksional, minat refrensial, minat preferensial dan minta eksploratif

\section{Hipotesis Penelitian}

Pengertian hipotesis menurut Sugiyono (2014) yaitu "Hipotesis merupakan jawaban sementara terhadap rumusan masalah. Karena sifatnya masih sementara, maka perlu dibuktikan kebenarannya melalui data empirik yang terkumpul". Adapun hipotesis yang penulis ajukan adalah sebagai berikut:

H1 : Diduga terdapat pengaruh positif dan signifikan antara promosi terhadap minat beli pada PT. Asuransi Jiwa Recapital di Jakarta.

H2 : Diduga terdapat pengaruh positif dan signifikan antara produk terhadap minat beli pada PT. Asuransi Jiwa Recapital di Jakarta.

H3 : Diduga terdapat pengaruh positif dan signifikan antara promosi dan produk secara bersama-sama terhadap minat beli pada PT. Asuransi Jiwa Recapital di Jakarta.

\section{METODOLOGI PENELITIAN}

\section{Tempat dan Waktu Penelitian}

Penulis mengadakan penelitian pada PT. Asuransi Jiwa Recapital dengan alamat pusat Recapital Building Jln. Adityawarman Kav. 55, Kebayoran Baru, Jakarta Selatan 12160, Telpon: (021) 7256272, Fax: (021) 7253858

\section{Populasi dan Sampel Populasi}

Populasi penelitian merupakan sekumpulan objek yang ditentukan melalui suatu kriteria tertentu yang akan dikategorikan ke dalam objek yang akan diteliti. Menurut Sugiyono (2014) mendefinisikan "Populasi adalah jumlah wilayah generalisasi yang terdiri atas obyek atau subyek yang mempunyai kualitas dan karakteristik yang ditetapkan oleh peneliti dan kemudian ditarik kesimpulannya. Adapun populasi dalam penelitian ini adalah pelanggan perusahaan.

\section{Sampel}

Menurut Sugiyono (2014) yaitu "Sampel adalah jumlah dan karakteristik yang dimiliki oleh populasi tersebut". Dalam pengambilan sampel dapat menggunakan sampling jenuh dimana menurut Sugiyono (2014) berpendapat "Sampling jenuh adalah teknik penentuan sampel bila semua anggota populasi digunakan sebagai sampel”. Istilah lain sampel jenuh adalah sensus, dimana anggota populasi di jadikan sebagai sampel. Dengan demikian sampel dalam penelitian ini adalah teknik sampling jenuh yaitu orang yang mewakili perusahaannya yang menjadi pelanggan PT. Asuransi Jiwa Recapital, dalam hal ini berjumlah 100 orang.

\section{Variabel Penelitian}

Dalam penelitian ini terdapat tiga variabel, yaitu variabel independen, variabel dependen dan variabel moderating, seperti berikut :

1. Variabel bebas (independent variable) Variabel bebas yang dalam hubungannya dengan variabel lain bertindak sebagai penyebab atau yang mempengaruhi variabel dependen. Pada penelitian ini sebagai variabel independen yakni promosi dan produk. Variabel independen sering disebut sebagai predictor yang dilambangkan dengan X.

2. Variabel terikat (dependent variable) Variabel yang tergantung dengan variabel lain, atau variabel yang dapat dipengaruhi oleh variabel lain. Sering disebut variabel respon di mana dalam penelitian ini adalah minat beli yang dilambangkan dengan $\mathrm{Y}$.

\section{Definisi Operasional Variabel}

Pengertian operasional variabel ini kemudian diuraikan menjadi indikator empiris yang meliputi :

1. Promosi $\left(\mathrm{X}_{1}\right)$

Variabel ini diukur melalui indikator :

a) periklanan (advertising), b) promosi 
penjualan (sales promotion), d) penjualan pribadi (personal selling), dan e) publisitas (publication).

2. Produk $\left(\mathrm{X}_{2}\right)$

Variabel ini diukur melalui indikator :a) kinerja (performance), b) daya tahan (durability) c), kesesuaian dengan spesifikasi (conformance to specifications), d) fitur (features), e) reliabilitas (reliability), f) estetika (aesthetics), g) kesan kualitas (perceived quality) dan h) kecepatan dan kemudahan (serviceability).

3. Minat Beli $(\mathrm{Y})$

Variabel ini diukur melalui indikator : a) minat transaksional, b) minat refrensial, c) minat preferensial dan d) minta eksploratif.

\section{Metode Pengumpulan Data}

\section{Kuesioner}

Dalam penelitian ini untuk mendapatkan data primer kuantitatif, penulis menghubungi responden yaitu pelanggan yang merupakan pelanggan yang secara rutin membeli produk di PT. Asuransi Jiwa Recapital.

\section{Wawancara}

Dalam penelitian ini untuk mendapatkan data primer kualitatif dengan metode wawancara, penulis datang ke kantor maupun pabrik PT. Asuransi Jiwa Recapital untuk melakukan studi pendahuluan dengan teknik wawancara langsung dengan pihak yang berkompeten dalam perusahaan, mengenai obyek yang diteliti.

\section{Studi Pustaka}

Untuk medapatkan data sekunder penulis melakukan dengan cara penelaahan terhadap literature-literature berupa buku-buku kuliah dan data yang diperoleh dalam bentuk yang sudah jadi, sudah diolah oleh pihak lain biasanya dalam bentuk publikasi serta bahanbahan yang berhubungan dengan masalah yang berkaitan dengan penelitian ini.

\section{Metode Analisis Data}

Metode analisis data yang digunakan dalam penelitan ini adalah:

\section{Uji Instrumen}

a. Uji Validitas

Valid adalah menunjukkan derajad ketepatan antara data yang sesungguhnya terjadi pada obyek dengan data yang dapat di- kumpulkan oleh peneliti. Menurut Sugiyono (2014) "Valid berarti terdapat kesamaan antara data yang terkumpul dengan data yang sesungguhnya".

Menurut Ghozali (2013) berpendapat "Suatu kuesioner dikatakan valid jika pertanyaan pada kuesioner mampu untuk mengungkapkan sesuatu yang akan diukur oleh kuesioner tersebut". Untuk melakukan uji validitas dilihat dari tabel Item-Total Statistics. Nilai tersebut dibandingkan dengan standar Chronbatch Alpha 0,30.

Kriteria atau syarat ketentuan keputusan suatu instrumen dikatakan valid dan tidaknya menurut Ghozali (2013) yaitu dengan membandingkan antara $\mathrm{r}_{\text {hitung }}$ (chronbatch Alpha) dengan 0,30 dengan ketentuan :

1). Jika chronbatch Alpha $>0,30$, maka instrumen valid,

2). Jika chronbatch Alpha $<0,30$, maka instrumen tidak valid.

\section{b. Uji Reliabilitas}

Model analisis uji reliabiltas yang digunakan dalam penelitian ini adalah model Alpha Cronbach. Menurut Ghozali (2013) "Reliabilitas merupakan alat untuk menguji kekonsistenan jawaban responden atas pertanyaan di kuesioner. Suatu kuesioner dikatakan reliabel jika jawaban seseorang terhadap pertanyaan adalah konsisten atau stabil dari waktu ke waktu".

Kriteria yang digunakan apabila suatu alat ukur memberikan hasil yang stabil, maka disebut alat ukur itu handal. Hasil ukur itu diterjemahkan dengan koefisien keandalan yaitu derajat kemampuan alat ukur mengukur perbedaan-perbedaan individu yang ada. Keandalan itu perlu, sebab data yang tidak andal atau bias tidak dapat diolah lebih lanjut karena akan menghasilkan kesimpulan yang bias. Pengukuran dilakukan sekali dan reliabilitas dengan uji statistik Cronbach Alpha (a). Dalam pengukurannya one shot akan dilakukan dengan analisis Cronbach's Alpha. Ghozali (2013) mengklasifikasikan nilai Cronbach's Alpha sebagai berikut: 


\begin{tabular}{|c|c|}
\hline \multicolumn{2}{|c|}{ Tabel 1. Pedoman Uji Reliabilitas } \\
\hline Nilai Cronbach's Alpha & Tingkat Reliabilitas \\
\hline $0,00-0,20$ & Kurang Reliabel \\
\hline $0,21-0,40$ & Agak Reliabel \\
\hline $0,41-0,60$ & Cukup Reliabel \\
\hline $0,61-0,80$ & Reliabel \\
\hline $0,81-1,00$ & Sangat Reliabel \\
\hline & Sumber : Gozali (2013) \\
\hline
\end{tabular}

\section{Uji Asumsi Klasik}

Uji asumsi klasik digunakan untuk mengetahui ketepatan sebuah data. Menurut Singgih Santoso (2011) berpendapat "Sebuah model regresi akan digunakan untuk melakukan peramalan, sebuah model yang baik adalah model dengan kesalahan peramalan yang seminimal mungkin. Karena itu, sebuah model sebelum digunakan seharusnya memenuhi beberapa asumsi, yang biasa disebut asumsi klasik". Dalam penelitian ini uji asumsi klasik yang digunakan adalah meliputi: Uji Normalitas, Uji Multikolinearitas, Uji Autokorelasi, dan Uji Heterokedastisitas

\section{a. Uji Normalitas}

Uji normalitas digunakan untuk menguji apakah dalam sebuah model regresi, variabel dependen, variabel independen, atau keduanya mempunyai distribusi normal atau tidak. Menurut Ghozali (2013) berpendapat "Model regresi yang baik adalah berdistribusi normal atau mendekati normal". Jadi uji normalitas bukan dilakukan pada masing-masing variabel tetapi pada nilai residualnya. Dengan demikian uji ini untuk memeriksa apakah data yang berasal dari populasi terdistribusi normal atau tidak. Uji normalitas dapat berpedoman pada uji Kolmogorov Smirnov dengan ketentuan sebagai berikut :

1). Jika nilai signifikansi $<0,05$ (taraf kepercayaan $95 \%$ ), maka data tidak berdistribusi normal.

2). Jika nilai signifikansi $>0,05$ (taraf kepercayaan $95 \%$ ), maka data berdistribusi normal.

\section{b. Uji Multikolinieritas}

Uji Multikoliniearitas ini bertujuan menguji apakah pada model regresi ditemukan adanya korelasi antar variabel independen. Menurut Ghozali (2013), berpendapat bahwa "Uji multikolinearitas bertujuan untuk menguji apakah pada model regresi ditemukan adanya korelasi antar variabel bebas (independen)". Model regresi yang baik seharusnya tidak terjadi korelasi di antara variabel independen. Jika variabel independen saling berkorelasi, maka variabel-variabel ini tidak ortogonal. Variabel ortogonal adalah variabel independen yang nilai korelasi antar sesama variabel independen sama dengan nol. Untuk mendeteksi ada tidaknya multikoliniearitas dalam model regresi dapat dilihat dari tolerance value atau Variance Inflation Factor (VIF) dengan ketentuan sebagai berikut:

1) Jika nilai nilai tolerance lebih $>$ dari 0.1 dan nilai Variance Inflation Factor (VIF) < dari 10 , maka tidak terjadi multikolinieritas.

2) Jika nilai nilai tolerance lebih $<$ dari 0.1 dan nilai Variance Inflation Factor (VIF) $>$ dari 10, maka terjadi multikolinieritas.

\section{c. Uji Autokorelasi}

Uji autokorelasi digunakan untuk mengetahui ada atau tidaknya penyimpangan asumsi klasik autokorelasi, yaitu adanya korelasi antar anggota sampel. Menurut Ghozali (2013) Uji autokorelasi bertujuan menguji apakah dalam model regresi liner ada korelasi antar kesalahan pengganggu pada periode $t$ dengan kesalahan pengganggu pada periode $\mathrm{t}-1$.

Autokorelasi muncul karena observasi yang berurutan sepanjang waktu berkaitan satu sama lainnya. Masalah ini timbul karena residual tidak bebas dari satu observasi ke observasi lainnya. Model regresi yang baik adalah regresi yang bebas dari autokorelasi. Cara yang dapat digunakan untuk menditeksi ada atau tidaknya autokorelasi dalam penelitian ini yaitu dengan uji Durbin-Watson (DW test) dengan berpedoman pada kriteria pedoman sebagai berikut:

\begin{tabular}{|c|c|}
\hline \multicolumn{2}{|c|}{ Tabel 1. Pedoman Uji Autokorelasi } \\
Dengan Memakai Uji Darbin-Watson (DW test) \\
\hline Kriteria & Keterangan \\
\hline$<1,000$ & Ada autokorelasi \\
\hline $1,100-1,540$ & Tanpa kesimpulan \\
\hline $1,550-2,460$ & Tidak ada autokorelasi \\
\hline $2,460-2,900$ & Tanpa kesimpulan \\
\hline$>2,900$ & Ada autokorelasi \\
\hline & Sumber : Algifari (2011) \\
\hline
\end{tabular}

d. Uji Heteroskesdastisitas

Menurut Ghozali (2013) "Uji heteroske- 
dastisitas bertujuan untuk mengetahui apakah dalam model regresi terjadi ketidaksamaan varian dari suatu residual pengamatan ke pengamatan lain". Untuk mengetahui ada tidaknya heteroskedastisitas adalah dengan menggunakan uji scatter plot dengan melihat grafik antara nilai prediksi variabel terikat (ZPRED) dan nilai residualnya (SRESID) dengan ketentuan sebagai berikut :

1) Jika penyebaran titik-titik pada data scatter plot membentuk pola tertentu yang teratur seperti gelombang besar melebar, kemudian menyempit, atau dengan baik turun mengelompok menjadi satu, maka telah terjadi heteroskedastisitas.

2) Jika titik-titik menyebar diatas dan dibawah angka 0 pada sumbu $Y$ tanpa membentuk pola tertentu, maka tidak terjadi problem heteroskedastisitas

\section{Analisis Deskriptif dan Verifikatif \\ a. Analisis Deskriptif}

Analisis dilakukan dengan melihat frekuensi dari pilihan opsi oleh responden yang disediakan pada setiap pertanyaan kuesioner yang diberikan. Dalam penelitian ini, untuk pembobotan data, peneliti menggunakan skala pengukuran. Menurut Sugiyono (2014), skala pengukuran merupakan kesepakatan yang digunakan sebagai acuan untuk menentukan panjang pendeknya interval yang ada dalam alat ukur sehingga alat ukur tersebut bila digunakan dalam pengukuran akan menghasilkan data. Adapun skala pengukuran yang digunakan dalam penelitian ini adalah dengan skala Likert.

\section{b. Analisis Verivikatif}

Analisis kuatitatif merupakan penelitian untuk menilai kondisi dari nilai pengaruh dan signifikansi pengaruh tersebut. Menurut Sugiyono (2014) "Metode verifikatif merupakan penelitian yang bertujuan untuk mengetahui hubungan antara 2 (dua) variabel atau lebih". Dengan demikian dari hasil dari analisis ini akan memberikan jawaban awal dari rumusan masalah mengenai pengaruh variabel independen terhadap variabel dependen. Adapun tahapan analisis yang dilakukan meliputi:

1) Analisis Regresi Linier Sederhana

Analisis regresi linier sederhana ini dalam penelitian ini dimaksudkan untuk menganalisis pengaruh secara par- sial antara variabel promosi $\left(\mathrm{X}_{1}\right)$ dan produk $\left(\mathrm{X}_{2}\right)$ terhadap minat beli $(\mathrm{Y})$.

2) Analisis Regresi Berganda

Di mana untuk mencapai tujuan penelitian yaitu menganalisis pengaruh promosi $\left(\mathrm{X}_{1}\right)$ dan produk $\left(\mathrm{X}_{2}\right)$ secara bersama-sama terhadap minat beli (Y) adalah dengan menggunakan analisis regresi berganda (Multiple regresional analisis).

3) Analisis Koefisien Korelasi

Analisis ini bertujuan untuk mengetahui tingkat keterhubungan atau pengaruh masing-masing variabel independen terhadap variabel dependennya. Dalam hal ini adalah promosi $\left(\mathrm{X}_{1}\right)$ dan produk $\left(\mathrm{X}_{2}\right)$ terhadap minat beli (Y) baik secara parsial maupun secara simultan.

\section{4) Analisis Koefisien Determinasi}

Dalam penelitian ini untuk mengetahui berapa besar prosentase kontribusi dari variabel promosi dan produk terhadap minat beli pada PT. Asuransi Jiwa Recapital di Jakarta baik secara parsial maupun secara simultan.

5) Pengujian Hipotesis

Pengujian hipotesis dimaksudkan untuk menguji dugaan sementara yang dirumuskan dalam hipotesis berdasarkan data empiris. Dalam penelitian ini pengujian hipotesis dilakukan dengan uji t dan uji F.

(a) Uji t (Parsial)

Uji t digunakan untuk menguji signifikansi variasi hubungan antar variabel $\mathrm{X}$ dan $\mathrm{Y}$, apakah variabel $\mathrm{X}_{1}$ dan $\mathrm{X}_{2}$ benar-benar berpengaruh secara parsial terhadap variabel dependen.

(b) Uji F (Simultan)

Pengujian hipotesis simultan (Uji F) bertujuan untuk mengetahui pengaruh secara bersama-sama variabel independen terhadap variabel dependen.

\section{Analisis dan Pembahasan \\ Analisis Deskriptif Variabel Penelitian}

Sesuai dengan tujuan analisis deskriptif yaitu untuk memberikan gambaran mengenai hasil penelitian secara umum, bagaimana karakteristik subyek penelitian sehubungan dengan variabel-variabel yang diteliti. Sebelum 
dilakukan analisis statistik terlebih dahulu dilakukan pembobotan terhadap skor masingmasing variabel. Pembobotan dilakukan dengan memberikan skor total dengan jumlah item dari variabel yang dibobot, melalui pertanyaaan yang diberikan penulis dalam kuesioner dapat di deskriptifkan setiap variabel yang diteliti.

Metode yang diambil dalam penelitian ini adalah metode pengukuran Likert. Dimana pertanyaan mengandung lima alternatif jawaban. Dan bentuk pertanyaan telah disusun menggunakan pengukuran Likert yang diberi bobot sebagai berikut:

\begin{tabular}{|c|c|}
\hline \multicolumn{2}{|c|}{ Tabel 2. Skala Likert } \\
\hline Jawaban & Bobot \\
\hline Sangat Baik (SB) & 5 \\
\hline Baik (B) & 4 \\
\hline Kurang Baik (KB) & 3 \\
\hline Tidak Baik (TB) & 2 \\
\hline Sangat Tidak Baik (STB) & 1 \\
\hline & Sumber : Sugiyono (2014) \\
\hline
\end{tabular}

$$
P=\frac{\text { RANGE }}{\text { KELAS }}=\frac{5-1}{5}=0,8
$$

Maka dapat ditetapkan interval sebagai berikut :

\begin{tabular}{|c|c|}
\hline \multicolumn{2}{|c|}{ Tabel 2 Rentang Skala } \\
\hline Nilai Rata-rata & Jawaban \\
\hline $1,00-1,79$ & Sangat Tidak Baik (STB) \\
\hline $1,80-2,59$ & Tidak Baik (TB) \\
\hline $2,60-3,39$ & Kurang Baik (KB) \\
\hline $3,40-4,19$ & Baik (B) \\
\hline $4,20-5,00$ & Sangat Baik (SB) \\
\hline & Sumber : Sugiyono (2014) \\
\hline
\end{tabular}

\section{Variabel Promosi $\left(\mathrm{X}_{1}\right)$}

Promosi merupakan kegiatan yang terencana yang esensinya adalah memperkenalkan, menawarkan sebuah produk maupun jasa kepada pelanggan dengan harapan pelanggan mengerti akan kegunaan dan manfaat dari produk atau jasa tersebut yang kemudian memiliki kemauan untuk membeli. Adapun dalam variabel ini diukur melalui indikator: a) periklanan (advertising), b) promosi penjualan (sales promotion), d) penjualan pribadi (personal selling), dan e) publisitas (publication). Adapun penilaian responden atas promosi dapat di paparkan sebagai berikut :

\begin{tabular}{|c|c|c|c|c|c|c|c|c|c|}
\hline \multicolumn{10}{|c|}{ Tabel 3. Variabel Promosi $\left(X_{1}\right)$} \\
\hline \multirow{2}{*}{ No } & \multirow{2}{*}{ Pernyataan } & STB & TB & KB & B & SB & \multirow{2}{*}{ Total } & \multirow{2}{*}{ Skor } & \multirow{2}{*}{ Ket. } \\
\hline & & (1) & (2) & (3) & (4) & (5) & & & \\
\hline 1 & Materi promosi jelas & 1 & 3 & 26 & 41 & 29 & 100 & 3.94 & Baik \\
\hline 2 & Efektivitas media iklan & 1 & 5 & 29 & 40 & 25 & 100 & 3.83 & Baik \\
\hline 3 & Menjelaskan dengan rinci & 1 & 2 & 25 & 46 & 26 & 100 & 3.94 & Baik \\
\hline 4 & Pesan dapat dipahami & 2 & 2 & 23 & 44 & 29 & 100 & 3.96 & Baik \\
\hline 5 & Pendekatan yang efektif & 1 & 3 & 25 & 48 & 23 & 100 & 3.89 & Baik \\
\hline 6 & Menjaga hubungan baik & 2 & 5 & 26 & 52 & 15 & 100 & 3.73 & Baik \\
\hline 7 & Mudah mendapat informasi & 2 & 5 & 38 & 39 & 16 & 100 & 3.62 & Baik \\
\hline \multirow[t]{2}{*}{8} & Preferensi kunjungan & 1 & 3 & 22 & 73 & 1 & 100 & 3.70 & Baik \\
\hline & \multicolumn{7}{|c|}{ Rata-rata Variabel Promosi } & 3.83 & Baik \\
\hline \multicolumn{10}{|c|}{ Sumber : Hasil Pengolahan Data Primer } \\
\hline
\end{tabular}

Bila dilihat dari tabel diatas rata-rata skor variabel promosi sebesar 3,83 masuk pada interval 3,40-4,19 atau dengan interpretasi setuju yang artinya responden mempunyai persepsi bahwa dalam melakukan promosi, perusahaan dinilai mampu memberikan informasi yang tepat serta penjelasan yang meyakinkan konsumen, dengan demikian kepercayaan pelanggan.

\section{Variabel Produk $\left(\mathrm{X}_{2}\right)$}

Produk merupakan bagian dari variabel bauran pemasaran yang memiliki keterkaitan langsung sebagai obyek dengan upaya untuk ditawarkan ke pasar untuk memenuhi kebutuhan dan keinginan pelanggan. Adapun variabel ini diukur melalui indikator: a) kinerja (performance), b) daya tahan (durability) c), kesesuaian dengan spesifikasi (conformance to specifications), d) fitur (features), e) reliabilitas 
(reliability), f) estetika (aesthetics), g) kesan kualitas (perceived quality) dan h) kecepatan dan kemudahan (serviceability).
Adapun penilaian responden atas produk yang dilaksanakan pada PT. Asuransi Jiwa Recapital dapat di paparkan sebagai berikut:

\begin{tabular}{|c|c|c|c|c|c|c|c|c|c|}
\hline \multirow{3}{*}{ No } & \multicolumn{9}{|c|}{ Tabel 4. Variabel Produk $\left(X_{2}\right)$} \\
\hline & \multirow{2}{*}{ Pernyataan } & STB & TB & KB & B & SB & \multirow{2}{*}{ Total } & \multirow{2}{*}{ Skor } & \multirow{2}{*}{ Ket } \\
\hline & & (1) & (2) & (3) & (4) & (5) & & & \\
\hline 1 & Produk berkualitas baik & 1 & 1 & 21 & 45 & 32 & 100 & 4.06 & Baik \\
\hline 2 & Produk dapat bersaing & 1 & 1 & 21 & 48 & 29 & 100 & 4.03 & Baik \\
\hline 3 & Memiliki banyak pilihan & 1 & 2 & 15 & 51 & 31 & 100 & 4.09 & Baik \\
\hline 4 & Asuransi sesuai manfaat & 1 & 1 & 22 & 49 & 27 & 100 & 4.00 & Baik \\
\hline 5 & Penerapan taris sesuai & 3 & 2 & 18 & 47 & 30 & 100 & 3.99 & Baik \\
\hline 6 & Jaminan asuransi beragam & 1 & 2 & 19 & 58 & 20 & 100 & 3.94 & Baik \\
\hline 7 & Asuransi yang bernilai tinggi & 2 & 5 & 31 & 39 & 23 & 100 & 3.76 & Baik \\
\hline \multirow[t]{2}{*}{8} & Pelayanan klaim cepat & 5 & 3 & 14 & 50 & 28 & 100 & 3.93 & Baik \\
\hline & \multicolumn{7}{|c|}{ Rata-rata Variabel Promosi } & 3.98 & Baik \\
\hline
\end{tabular}

Bila dilihat dari tabel diatas rata-rata skor variabel minat beli sebesar 3,98 masuk pada interval 3,40-4,19 atau dengan interpretasi setuju yang artinya responden mempunyai persepsi bahwa perusahaan memiliki kemampuan yang baik dalam hal peningkatan jenis produk asuransi yang bervariasi asuransi sesuai dengan peruntukannya.

\section{Variabel Minat beli $(\mathrm{Y})$}

Minat beli merupakan perilaku konsumen tidak hanya tentang apa yang dibeli atau dikonsumsi oleh konsumen saja, tetapi juga dimana, bagaimana kebiasaan dan dalam kondisi macam apa produk dan jasa yang dibeli. Adapun variabel ini diukur melalui indikator: a) minat transaksional, b) minat refrensial, c) minat preferensial dan d) minta eksploratif. Adapun penilaian responden atas minat beli yang dilaksanakan pada PT. Asuransi Jiwa Recapital dapat di paparkan sebagai berikut:

\begin{tabular}{|c|c|c|c|c|c|c|c|c|c|}
\hline \multicolumn{10}{|c|}{ Tabel 5. Variabel Minat Beli $(Y)$} \\
\hline \multirow{2}{*}{ No } & \multirow{2}{*}{ Pernyataan } & STB & TB & KB & B & SB & \multirow{2}{*}{ Total } & \multirow{2}{*}{ Skor } & \multirow{2}{*}{ Ket. } \\
\hline & & (1) & (2) & (3) & (4) & (5) & & & \\
\hline 1 & Variasi produk & 1 & 2 & 19 & 44 & 34 & 100 & 4.08 & Baik \\
\hline 2 & Promosi tidak membohongi & 1 & 5 & 33 & 36 & 25 & 100 & 3.79 & Baik \\
\hline 3 & Harga premi terjangkau & 1 & 3 & 20 & 41 & 35 & 100 & 4.06 & Baik \\
\hline 4 & Penuh pertimbangan & 1 & 3 & 17 & 46 & 33 & 100 & 4.07 & Baik \\
\hline 5 & Membutuhkan produk & 1 & 2 & 26 & 40 & 31 & 100 & 3.98 & Baik \\
\hline 6 & Melakukan pembelian & 1 & 1 & 22 & 44 & 32 & 100 & 4.05 & Baik \\
\hline 7 & Kecermatan pembelian & 2 & 2 & 17 & 55 & 24 & 100 & 3.97 & Baik \\
\hline \multirow[t]{2}{*}{8} & Kepercayaan produk & 1 & 1 & 18 & 52 & 28 & 100 & 4.05 & Baik \\
\hline & \multicolumn{7}{|c|}{ Rata-rata Variabel Minat Beli } & 4.01 & Baik \\
\hline \multicolumn{10}{|c|}{ Sumber : Hasil Pengolahan Data Prime } \\
\hline
\end{tabular}

Bila dilihat dari tabel diatas rata-rata skor variabel minat beli sebesar 4,01 masuk pada interval 3,40-4,19 atau dengan interpretasi setuju yang artinya responden mempunyai persepsi bahwa perusahaan memiliki kemampuan yang baik dalam hal pemenuhan ke- inginan dan kebutuhan sehingga pelanggan memiliki komitmen untuk membeli.

\section{Pengujian Instrumen Data}

1. Hasil Uji Valiiditas

Berdasar perhitungan dengan mengguna- 
kan menggunakan Software IBM SPSS (Statistical Program for Social Science) versi 24.00 for windows. Seluruh butir pernyataan yang digunakan dalam penelitian diperoleh nilai Chronbatch Alpha $>0.30$ dan nilai r positif, dengan demikian maka semua butir pernyataan dikatakan valid.

\section{Hasil Uji Reliabilitas}

Berdasar perhitungan dengan menggunakan menggunakan Software IBM SPSS (Statistical Program for Social Science) versi 24.00 for windows. Seluruh butir pernyataan diperoleh nilai Cronbach Alfa lebih besar dari 0.60 dan nilai $r$ bernilai positif, dengan demikian maka butir pernyataan dalam variabel dalam penelitian dikatakan reliabel dan data layak untuk diolah ke pengujian berikutnya.

\section{Pengujian Asumsi Klasik}

\section{Uji Normalitas}

Uji normalitas dilakukan untuk menguji apakah dalam model regresi, variabel dependen dan variabel independen berdistribusi normal atau berdistribusi tidak normal. Berikut ini Hasil uji normalitas dengan alat uji KolmogorovSmirnov Test, sebagai berikut:

\begin{tabular}{|c|r|c|c|r|c|r|}
\hline Tabel 6. Hasil Normalitas Dengan Kolmogorov-Smirnov Test \\
\hline & \multicolumn{3}{|c|}{$\begin{array}{c}\text { Kolmogorov- } \\
\text { Smirnov }\end{array}$} & \multicolumn{3}{c|}{ Shapiro-Wilk } \\
\cline { 2 - 7 } & Statistic & Df & Sig. & Statistic & df & Sig. \\
\hline Minat Beli $(Y)$ & .085 & 100 & .071 & .979 & 100 & .116 \\
\hline \multicolumn{6}{|c|}{ Sumber : Data primer diolah. } \\
\hline
\end{tabular}

Berdasarkan hasil pengujian pada tabel di atas, diperoleh nilai signifikansi $\alpha=0,071$ dimana nilai tersebut lebih besar dari nilai a $=0,050$ atau $(0,071>0,05)$. Dengan demikian maka asumsi distribusi persamaan pada uji ini adalah normal.

\section{Uji Multikonilieritas}

Pengujian mutlikolinearitas dilakukan untuk meyakini bahwa antar variabel bebas tidak memiliki multikolinearitas atau tidak memiliki hubungan korelasi antara variabel yang ditetapkan sebagai model dalam penelitian, karena model regresi yang baik seharusnya tidak terjadi korelasi di antara variabel independen. Uji multikolinearitas dilakukan dengan melihat nilai Tolerance Value dan Variance Inflation Factor (VIF). Adapun hasil pengujiannya seba- gai berikut:

\begin{tabular}{|c|c|c|}
\hline \multirow{2}{*}{ Tabel 7. Hasil Uji Multikolinieritas dengan Collinierity Statistic } \\
\cline { 2 - 3 } & Collinearity Statistics \\
\hline 1 (Constant) & & VIF \\
\hline Promosi $\left(X_{1}\right)$ & .938 & 1.067 \\
\hline Produk $\left(X_{2}\right)$ & .938 & 1.067 \\
\hline \multicolumn{3}{|c|}{ Sumber: Data diolah } \\
\hline
\end{tabular}

Berdasarkan hasil pengujian pada tabel di atas, nilai tolerance masing-masing variabel bebas yaitu $0,938<1,0$ dan nilai Variance Inflation Factor (VIF) sebesar 1,067 < 10, dengan demikian model regresi ini tidak ada multikolinearitas.

\section{Uji Autokorelasi}

Pengujian Autokorelasi digunakan untuk mengetahui ada atau tidaknya penyimpangan korelasi antar anggota sampel. Pengujian dilakukan dengan alat uji Darbin-Watson (DW test). Adapun hasil pengujiannya sebagai berikut:

\begin{tabular}{|l|r|r|r|r|r|}
\hline \multicolumn{7}{|c|}{ Tabel 8. Hasil Uji Autokorelasi } \\
\hline Model & \multicolumn{1}{|c|}{ R } & R Square & $\begin{array}{c}\text { Adjusted R } \\
\text { Square }\end{array}$ & $\begin{array}{c}\text { Std. Error of } \\
\text { the Estimate }\end{array}$ & $\begin{array}{r}\text { Durbin- } \\
\text { Watson }\end{array}$ \\
\hline 1 & $.601^{\mathbf{a}}$ & .361 & .348 & 2.925 & 2.197 \\
\hline \multicolumn{8}{|c|}{ Sumber : Data primer diolah } \\
\hline
\end{tabular}

Berdasarkan hasil pengujian pada tabel di atas, model regresi ini tidak ada autokorelasi, hal ini dibuktikan dengan nilai Durbin-Watson sebesar 2.197 yang berada diantara interval $1.550-2.460$

\section{Uji Heteroskesdastisitas}

Pengujian heteroskedastisitas dimaksudkan untuk menguji apakah dalam sebuah model regresi terjadi ketidaksamaan varians residual. Salah satu cara untuk mendeteksi ada tidaknya heteroskedastisitas adalah dengan uji scater plot. Adapun hasil nya sebagai berikut:

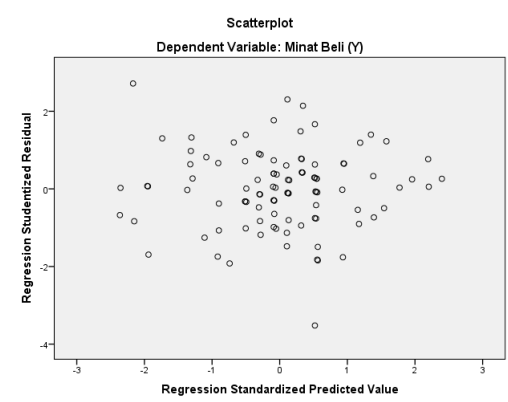

Gambar 1 Hasil Uji Heteroskedastisitas 
Berdasarkan gambar di atas, disimpulkan tidak terdapat gangguan heteroskedastisitas, hal ini dibuktikan dengan titik-titik pada grafik scatterplot tidak mempunyai pola penyebaran yang jelas dan titik-titik tersebut menyebar di atas dan dibawah angka 0 (nol) pada sumbu Y.

\section{Hasil Analisis Data}

Pada bagian pengujian ini dimaksudkan untuk menunjukkan hasil dari pengujian atas variabel Promosi $\left(\mathrm{X}_{1}\right)$ dan Produk $\left(\mathrm{X}_{2}\right)$ Terhadap Minat beli (Y). Adapun hasil analisis dalam penelitian ini sebagai berikut:

\section{Analisis Regresi Linier Sederhana}

Uji regresilinier sederhanaini dimaksudkan untuk mengetahui seberapa besar pengaruh variabel promosi $\left(\mathrm{X}_{1}\right)$ dan produk $\left(\mathrm{X}_{2}\right)$ terhadap minat beli $(\mathrm{Y})$ secara sendiri-sendiri. Adapun hasil analisis regresi linier sederhana sebagai berikut Berdasarkan perhitungan regresi berganda menggunakan program IBM SPSS (Statistical Program for Social Science) versi 24.00 for windows, diperoleh hasil sebagai berikut :

\begin{tabular}{|c|c|c|c|c|c|}
\hline \multicolumn{6}{|c|}{$\begin{array}{l}\text { Tabel 10. Hasil Uji Regresi Linier Sederhana } \\
\text { Antara Promosi }\left(\mathrm{X}_{1}\right) \text { Terhadap Minat Beli }(\mathrm{Y})\end{array}$} \\
\hline \multicolumn{6}{|c|}{ Coefficients $^{a}$} \\
\hline \multirow[b]{2}{*}{ Model } & \multicolumn{2}{|c|}{$\begin{array}{l}\text { Unstandardized } \\
\text { Coefficients }\end{array}$} & \multicolumn{3}{|c|}{ Standardized Coefficients } \\
\hline & B & Std. Error & Beta & $t$ & Sig. \\
\hline 1 (Constant) & 14.160 & 3.467 & & 4.084 & .000 \\
\hline Promosi $\left(X_{1}\right)$ & .584 & .113 & .464 & 5.182 & .000 \\
\hline
\end{tabular}

Dari hasil perhitungan pada tabel di atas dapat disajikan ke dalam bentuk persamaan regresi standardized: $\mathrm{Y}=\mathbf{1 4 , 1 6 0}+\mathbf{0 , 5 8 4 X _ { 1 }}$.

Adapun persamaan tersebut dapat dijelaskan sebagai berikut :

a. Konstanta sebesar 14,160, menyatakan bahwa tanpa dipengaruhi variabel promosi maka besarnya nilai minat beli sudah terbentuk sebesar 14,160.

b. Variabel promosi $\left(\mathrm{X}_{1}\right)$ berpengaruh positif terhadap minat beli (Y) dengan nilai koefisien sebesar 0,584. Yang artinya jika variabel promosi $\left(\mathrm{X}_{1}\right)$ meningkat satu satuan dengan asumsi variabel lain tetap, maka minat beli akan meningkat sebesar 0,584 satuan.

\begin{tabular}{|c|c|c|c|c|c|}
\hline \multicolumn{6}{|c|}{$\begin{array}{l}\text { Tabel 11. Hasil Uji Regresi Linier Sederhana } \\
\text { Antara Produk }\left(\mathrm{X}_{2}\right) \text { Terhadap Minat Beli }(\mathrm{Y})\end{array}$} \\
\hline \multicolumn{6}{|c|}{ Coefficients $^{a}$} \\
\hline \multirow[b]{2}{*}{ Model } & \multicolumn{2}{|c|}{$\begin{array}{l}\text { Unstandardized } \\
\text { Coefficients }\end{array}$} & \multicolumn{3}{|c|}{ Standardized Coefficients } \\
\hline & B & Std. Error & Beta & $t$ & Sig. \\
\hline 1 (Constant) & 14.771 & 3.157 & & 4.679 & .000 \\
\hline Produk $\left(X_{2}\right)$ & .543 & .099 & .486 & 5.501 & .000 \\
\hline
\end{tabular}

Dari hasil perhitungan pada tabel di atas dapat disajikan ke dalam bentuk persamaan

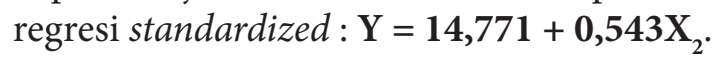

Adapun persamaan tersebut dapat dijelaskan sebagai berikut :

a. Konstanta sebesar 14,771, menyatakan bahwa tanpa dipengaruhi variabel produk, maka besarnya nilai minat beli sudah terbentuk sebesar 14,771.

b. Variabel produk $\left(\mathrm{X}_{2}\right)$ berpengaruh positif terhadap minat beli (Y) dengan nilai koefisien sebesar 0,543. Yang artinya jika variabel produk $\left(\mathrm{X}_{2}\right)$ meningkat satu satuan dengan asumsi variabel lain tetap, maka minat beli akan meningkat sebesar 0,543 satuan

\section{Analisis Regresi Berganda}

Analisis regresi berganda dimaksudkan untuk mengetahui seberapa besar pengaruh variabel promosi $\left(\mathrm{X}_{1}\right)$ dan produk $\left(\mathrm{X}_{2}\right)$ terhadap minat beli (Y). Berdasarkan perhitungan regresi berganda menggunakan program IBM SPSS (Statistical Program for Social Science) versi 22.00 for windows, diperoleh hasil sebagai berikut :

\begin{tabular}{|l|r|r|r|r|r|}
\hline \multicolumn{6}{|c|}{ Tabel 12. Hasil Uji Regresi Berganda } \\
\hline \multirow{3}{*}{ Coefficients } \\
\hline \multirow{2}{*}{ Model } & $\begin{array}{c}\text { Unstandardized } \\
\text { Coefficients }\end{array}$ & \multicolumn{2}{|c|}{ Standardized Coefficients } \\
\cline { 2 - 7 } 1 (Constant) & \multicolumn{1}{|c|}{ B } & Std. Error & \multicolumn{1}{|c|}{ Beta } & \multicolumn{1}{c|}{ S } & \multicolumn{1}{c|}{ Sig. } \\
\hline Promosi $\left(X_{1}\right)$ & 3.930 & 3.823 & & 1.028 & .307 \\
\hline Produk $\left(X_{2}\right)$ & .460 & .106 & .365 & 4.357 & .000 \\
\hline & .441 & .094 & .395 & 4.706 & .000 \\
\hline
\end{tabular}

Berdasarkan hasil perhitungan pada tabel di atas dapat disajikan ke dalam bentuk persamaan regresi standardized sebagai berikut :

$$
\mathrm{Y}=3,930+0,460 \mathrm{X}_{1}+\mathbf{0 , 4 4 1 \mathrm { X } _ { 2 }}
$$

Keterangan:

$\mathrm{Y}=$ Variabel Minat Beli 
$\mathrm{X}_{1}=$ Variabel Promosi

$\mathrm{X}_{2}=$ Variabel Produk

Adapun persamaan tersebut dapat dijelaskan sebagai berikut:

a. Nilai konstanta diperoleh sebesar 3,930, menyatakan bahwa tanpa dipengaruhi oleh variabel promosi dan produk besarnya nilai minat beli sudah terbentuk sebesar 3,930 point.

b. Variabel promosi $\left(\mathrm{X}_{1}\right)$ berpengaruh positif dan signifikan terhadap minat beli $(\mathrm{Y})$ dengan nilai koefisien sebesar 0,460 . Hal ini diartikan bahwa jika variabel promosi $\left(\mathrm{X}_{1}\right)$ meningkat satu satuan dengan asumsi variabel produk $\left(\mathrm{X}_{2}\right)$ tetap atau konstan $(0)$, maka minat beli (Y) juga akan mengalami peningkatan 0,460 satuan.

c. Variabel produk $\left(\mathrm{X}_{2}\right)$ berpengaruh positif dan signifikan terhadap minat beli $(\mathrm{Y})$ dengan nilai koefisien sebesar 0,441 . Hal ini diartikan bahwa jika variabel produk $\left(\mathrm{X}_{2}\right)$ meningkat satu satuan dengan asumsi variabel promosi $\left(\mathrm{X}_{1}\right)$ tetap atau konstan (0), maka minat beli $(Y)$ juga akan mengalami peningkatan sebesar 0,441 satuan.

\section{Analisis Koefisien Korelasi}

Analisis koefisien korelasi (R) digunakan untuk mengetahui tingkat kekuatan hubungan atau pengaruh dari variabel bebas terhadap variabel terikat, dalam hal ini adalah variabel promosi dan produk baik secara parsial maupun secara bersama-sama terhadap minat beli. Adapun hasil pengolahan data dapat dijelaskan sebagai berikut :

\begin{tabular}{|c|c|c|c|}
\hline \multicolumn{4}{|c|}{$\begin{array}{l}\text { Tabel 13. Hasil Uji Koefisien Korelasi } \\
\text { Pengaruh Promosi }\left(\mathrm{X}_{1}\right) \text { Terhadap Minat Beli }(\mathrm{Y})\end{array}$} \\
\hline \multicolumn{4}{|c|}{ Coefficients $^{b}$} \\
\hline & & $\operatorname{CAR}\left(X_{1}\right)$ & ROA (Y) \\
\hline \multirow{2}{*}{ Promosi $\left(X_{1}\right)$} & Pearson Correlation & 1 & $.464^{* *}$ \\
\hline & Sig. (2-tailed) & & .000 \\
\hline \multirow{2}{*}{ Minat Beli (Y) } & Pearson Correlation & $.464^{* *}$ & 1 \\
\hline & Sig. (2-tailed) & .000 & \\
\hline
\end{tabular}

Berdasarkan hasil pada tabel di atas diperoleh nilai korelasi sebesar 0,464. Hal ini menunjukkan bahwa variabel promosi $\left(\mathrm{X}_{1}\right)$ secara parsial memiliki tingkat hubungan yang sedang terhadap minat beli (Y).

\begin{tabular}{|l|l|r|r|}
\hline \multicolumn{4}{|c|}{$\begin{array}{c}\text { Tabel 14. Hasil Uji Koefisien Korelasi } \\
\text { Pengaruh Produk }\left(\mathbf{X}_{2}\right) \text { Terhadap Minat Beli }(Y)\end{array}$} \\
\multicolumn{4}{|c|}{ Coefficients } \\
\hline \multirow{3}{*}{ Produk $\left(X_{2}\right)$} & CAR $\left(X_{1}\right)$ & \multicolumn{1}{|c|}{ ROA $(Y)$} \\
\hline \multirow{3}{*}{ Minat Beli $(Y)$} & Pearson Correlation & 1 & $.464^{* *}$ \\
\cline { 2 - 5 } & Sig. (2-tailed) & & .000 \\
\hline & Pearson Correlation & $.464^{* *}$ & 1 \\
\cline { 2 - 5 } & Sig. (2-tailed) & .000 & \\
\hline & \multicolumn{3}{|c|}{ Sumber : Data primer diolah } \\
\hline
\end{tabular}

Berdasarkan hasil pada tabel di atas diperoleh nilai korelasi sebesar 0486. Hal ini menunjukkan bahwa variabel produk $\left(\mathrm{X}_{2}\right)$ secara parsial memiliki tingkat hubungan yang sedang terhadap minat beli $(\mathrm{Y})$.

\begin{tabular}{|c|c|c|c|c|}
\hline \multicolumn{5}{|c|}{$\begin{array}{l}\text { Tabel 15. Hasil Uji Koefisien Korelasi Pengaruh Promosi }\left(X_{1}\right) \\
\text { dan Produk }\left(X_{2}\right) \text { secara simultan Terhadap Minat Beli }(Y)\end{array}$} \\
\hline \multicolumn{5}{|c|}{ Model Summary } \\
\hline Model & $\mathbf{R}$ & R Square & Adjusted R Square & $\begin{array}{l}\text { Std. Error of } \\
\text { the Estimate }\end{array}$ \\
\hline 1 & $.601^{\mathrm{a}}$ & .361 & .348 & 2.925 \\
\hline
\end{tabular}

Berdasarkan hasil pada tabel di atas diperoleh nilai korelasi sebesar 0,601 . Hal ini menunjukkan bahwa variabel promosi $\left(\mathrm{X}_{1}\right)$ dan produk $\left(\mathrm{X}_{2}\right)$ secara simultan memiliki tingkat hubungan yang kuat terhadap minat beli (Y).

\section{Analisis Koefisien Determinasi}

Analisis koefisien deteminasi $(\mathrm{Kd})$ digunakan untuk mengetahui kontribusi besarnya pengaruh antara variabel bebas terhadap variabel terikat, dalam hal ini adalah variabel promosi dan produk baik secara parsial maupun secara bersama-sama terhadap minat beli. Adapun hasil pengolahan data dapat dijelaskan sebagai berikut :

\begin{tabular}{|c|r|r|r|r|}
\hline \multicolumn{5}{|c|}{$\begin{array}{c}\text { Tabel 16. Hasil Uji Koefisien Determinasi } \\
\text { Pengaruh Promosi }\left(X_{1}\right) \text { Terhadap Minat Beli }(Y)\end{array}$} \\
\hline Model & \multicolumn{1}{|c|}{ R } & R Square & Adjusted R Square & $\begin{array}{r}\text { Std. Error of } \\
\text { the Estimate }\end{array}$ \\
\hline 1 & $.464^{\mathrm{a}}$ & .215 & .207 & 3.225 \\
\hline \multicolumn{7}{|c|}{ Sumber : Data primer diolah } \\
\hline
\end{tabular}

Berdasarkan hasil pada tabel di atas dapat dilihat bahwa nilai $R$ Square sebesar 0,215 atau $21,5 \%$. Hal ini menunjukkan bahwa pengaruh promosi secara parsial terhadap minat beli adalah sebesar $21,5 \%$, sedangkan sisanya sebesar $78,5 \%$ dipengaruhi oleh faktor lain yang tidak diteliti. 


\begin{tabular}{|l|r|r|r|r|}
\hline \multicolumn{7}{|c|}{$\begin{array}{c}\text { Tabel 17. Hasil Uji Determinasi Pengaruh } \\
\text { Produk }\left(\mathrm{X}_{2}\right) \text { Terhadap Minat Beli }(\mathrm{Y})\end{array}$} \\
\hline Model & \multicolumn{1}{|c|}{ R } & R Square & Adjusted R Square & $\begin{array}{r}\text { Std. Error of } \\
\text { the Estimate }\end{array}$ \\
\hline 1 & $.486^{2}$ & .236 & .228 & 3.182 \\
\hline \multicolumn{7}{|c|}{ Sumber : Data primer diolah } \\
\hline
\end{tabular}

Berdasarkan hasil pada tabel di atas dapat dilihat bahwa nilai $R$ Square sebesar 0,235 atau $23,5 \%$. Hal ini menunjukkan bahwa pengaruh produk secara parsial terhadap minat beli adalah sebesar $33,8 \%$, sedangkan sisanya sebesar $23,5 \%$ dipengaruhi oleh faktor lain yang tidak diteliti.

\begin{tabular}{|c|c|c|c|c|}
\hline \multicolumn{5}{|c|}{$\begin{array}{l}\text { Tabel 18. Hasil Uji Koefisien Determinasi Pengaruh } \\
\text { Promosi }\left(\mathrm{X}_{1}\right) \text { dan Produk }\left(\mathrm{X}_{2}\right) \text { Terhadap Minat Beli }(\mathrm{Y})\end{array}$} \\
\hline \multicolumn{5}{|c|}{ Model Summary } \\
\hline Model & $\mathbf{R}$ & R Square & Adjusted R Square & $\begin{array}{l}\text { Std. Error of } \\
\text { the Estimate }\end{array}$ \\
\hline 1 & $.601^{\mathrm{a}}$ & .361 & .348 & 2.925 \\
\hline \multicolumn{5}{|c|}{ Sumber : Data primer diolah } \\
\hline
\end{tabular}

Berdasarkan hasil pada tabel di atas dapat dilihat bahwa nilai $R$ Square sebesar 0,361 atau $36,1 \%$. Hal ini menunjukkan bahwa pengaruh promosi $\left(\mathrm{X}_{1}\right)$ dan produk $\left(\mathrm{X}_{2}\right)$ secara bersamasama terhadap minat beli $(\mathrm{Y})$ adalah sebesar $36,1 \%$, sedangkan sisanya sebesar $63,9 \%$ dipengaruhi oleh faktor lain yang tidak diteliti.

\section{Pengujian Hipotesis}

Pengujian hipotesis dimaksudkan untuk menetukan apakah sebaiknya hipotesis diterima atau ditolak. Dalam pengujian ini digunakan uji $\mathrm{t}$ (parsial) dan uji F (Simultan).

\section{a. Uji Hipotesis Parsial (Uji t)}

Pengujian hipotesis secara parsial menggunakan uji t yaitu untuk menguji bagaimana pengaruh masing-masing variabel bebas secara sendiri-sendiri terhadap variabel terikatnya.

Hipotesis Pertama : Terdapat pengaruh positif dan signifikan antara promosi terhadap minat beli.

\begin{tabular}{|c|c|c|c|c|c|}
\hline \multicolumn{6}{|c|}{$\begin{array}{l}\text { Tabel 19. Pengujian Hipotesis Variabel } \\
\text { Promosi }\left(X_{1}\right) \text { Terhadap Minat Beli }(Y)\end{array}$} \\
\hline \multicolumn{6}{|c|}{ Coefficients $^{a}$} \\
\hline \multirow[b]{2}{*}{ Model } & \multicolumn{2}{|c|}{$\begin{array}{l}\text { Unstandardized } \\
\text { Coefficients }\end{array}$} & \multicolumn{3}{|c|}{ Standardized Coefficients } \\
\hline & B & Std. Error & Beta & $t$ & Sig. \\
\hline 1 (Constant) & 14.160 & 3.467 & & 4.084 & .000 \\
\hline Promosi $\left(X_{1}\right)$ & .584 & .113 & .464 & 5.182 & .000 \\
\hline \multicolumn{6}{|c|}{ Sumber : Data primer diolah } \\
\hline
\end{tabular}

Berdasarkan hasil pengolahan data di atas, diperoleh nilai $\mathrm{t}_{\text {hitung }}>\mathrm{t}_{\text {tabel }}$ atau $(5,182>1,984)$, hal itu juga diperkuat dengan signifikansi 0,000 $<0,05$. Dengan demikian hipotesis pertama yang menyatakan terdapat pengaruh positif dan signifikan antara promosi terhadap minat beli dapat diterima.

Hipotesis Kedua : Terdapat pengaruh positif dan signifikan antara produk terhadap minat beli.

\begin{tabular}{|c|c|c|c|c|c|}
\hline \multicolumn{6}{|c|}{$\begin{array}{l}\text { Tabel 20. Pengujian Hipotesis Variabel } \\
\text { Produk }\left(\mathrm{X}_{2}\right) \text { Terhadap Minat Beli }(\mathrm{Y})\end{array}$} \\
\hline \multicolumn{6}{|c|}{ Coefficients ${ }^{\mathrm{a}}$} \\
\hline \multirow[b]{2}{*}{ Model } & \multicolumn{2}{|c|}{$\begin{array}{l}\text { Unstandardized } \\
\text { Coefficients }\end{array}$} & \multicolumn{3}{|c|}{ Standardized Coefficients } \\
\hline & B & Std. Error & Beta & $t$ & Sig. \\
\hline 1 (Constant) & 14.771 & 3.157 & & 4.679 & .000 \\
\hline $\operatorname{Produk}\left(X_{2}\right)$ & .543 & .099 & .486 & 5.501 & .000 \\
\hline
\end{tabular}

Berdasarkan hasil pengolahan data di atas, diperoleh nilai $\mathrm{t}_{\text {hitung }}>\mathrm{t}_{\text {tabel }}$ atau $(5,405>1,984)$, hal itu juga diperkuat dengan nilai signifikansi $0,000<0,05$. Dengan demikian hipotesis kedua yang menyatakan terdapat pengaruh positif dan signifikan antara produk terhadap minat beli dapat diterima.

\section{b. Uji Hipotesis Secara Simultan (Uji F)}

Pengujian hipotesis secara simultan dimaksudkan untuk mengetahui pengaruh semua variabel bebas terhadap variabel terikat yaitu promosi dan produk terhadap minat beli. Dalam pengujian ini digunakan uji $\mathrm{F}$.

Hipotesis Ketiga : Terdapat pengaruh positif dan signifikan antara promosi $\left(\mathrm{X}_{1}\right)$ dan produk $\left(\mathrm{X}_{2}\right)$ secara simultan terhadap minat beli (Y) pada PT. Bisma Naredra di Jakarta.

Adapun hasil pengujiannya sebagai berikut:

\begin{tabular}{|c|c|c|c|c|c|c|}
\hline \multicolumn{7}{|c|}{$\begin{array}{c}\text { Tabel 21. Pengujian Hipotesis Secara Simultan } \\
\text { ANOVA }^{\text {a }}\end{array}$} \\
\hline \multicolumn{2}{|c|}{ Model } & $\begin{array}{l}\text { Sum of } \\
\text { Squares }\end{array}$ & df & $\begin{array}{l}\text { Mean } \\
\text { Square }\end{array}$ & $\mathbf{F}$ & Sig. \\
\hline \multirow{3}{*}{1} & Regression & 468.850 & 2 & 234.425 & 27.400 & $.000^{\mathrm{b}}$ \\
\hline & Residual & 829.900 & 97 & 8.556 & & \\
\hline & Total & 1298.750 & 99 & & & \\
\hline \multicolumn{7}{|c|}{ Sumber : Data primer diolah } \\
\hline
\end{tabular}

Berdasarkan hasil pengolahan data di atas, diperoleh nilai $\mathrm{F}_{\text {hitung }}>\mathrm{F}_{\text {tabel }}$ atau $(27,400>2,700)$, hal itu juga diperkuat dengan nilai signifikansi $0,000<0,05$. Dengan demikian hipotesis ketiga 
yang menyatakan terdapat pengaruh positif dan signifikan antara promosi dan produk secara simultan terhadap minat beli dapat diterima.

\section{HASIL PENELITIAN DAN PEMBAHASAN}

Dari hasil pengujian statistik dan analisis diatas, maka dapat dipaparkan analisis pengaruh promosi dan produk terhadap minat beli pada PT. Asuransi Jiwa Recapital di Jakarta, sebagai berikut :

\section{Pengaruh Promosi Terhadap Minat Beli \\ Pada PT. Asuransi Jiwa Recapital di \\ Jakarta.}

Dari hasil analisis statistik, diperoleh persamaan model regresi adalah $\mathrm{Y}=14,160$ $+0,584 \mathrm{X}_{1}$. Konstansta memiliki nilai positif sehingga apabila promosi mengalami kenaikan, maka minat beli juga akan meningkat.

Koefisien korelasi antara promosi terhadap minat beli adalah sebesar 0,464. Dengan demikian dapat dikatakan bahwa kedua variabel memiliki hubungan yang positif sebesar 0,464 dengan tingkat hubungan atau pengaruh sedang.

Nilai koefisien determinasi diperoleh sebesar 0,215, data tersebut mengindikasikan bahwa variabel promosi memberikan kontribusi pengaruh sebesar $21,5 \%$ terhadap minat beli pada PT. Asuransi Jiwa Recapital di Jakarta.

Uji hipotesis diperoleh nilai $\mathrm{t}_{\text {hitung }}>\mathrm{t}_{\text {tabel }}$ atau $(5,182>1,984)$ dan signifikansi $t<0,05$ atau $(0,000<0,05)$. Dengan demikian hipotesis $\mathrm{H}_{1}$ yang penulis ajukan dapat diterima, hal ini menunjukkan bahwa promosi berpengaruh positif dan siginifikan terhadap minat beli pada PT. Asuransi Jiwa Recapital di Jakarta.

\section{Pengaruh Produk Terhadap Minat Beli Pada PT. Asuransi Jiwa Recapital di Jakarta.}

Dari hasil analisis statistik, diperoleh persamaan model regresi adalah $\mathrm{Y}=14,771$ $+0,543 \mathrm{X}_{2}$. Konstansta memiliki nilai positif sehingga apabila produk mengalami keunggulan bersaing yang baik, maka minat beli juga akan meningkat.

Koefisien korelasi antara produk terhadap minat beli adalah sebesar 0,486. Dengan demikian dapat dikatakan bahwa kedua variabel memiliki hubungan yang positif sebesar 0,486 dengan tingkat hubungan atau pengaruh sedang.

Nilai koefisien determinasi diperoleh sebesar 0,236, data tersebut mengindikasikan bahwa variabel produk memberikan kontribusi pengaruh sebesar 23,6\% terhadap minat beli pada PT. Asuransi Jiwa Recapital di Jakarta.

Uji hipotesis diperoleh nilai $\mathrm{t}_{\text {hitung }}>{ }_{\text {ttabel }}$ atau $(5,405>1,984)$ dan signifikansi $t<0,05$ atau $(0,000<0,05)$. Dengan demikian hipotesis $\mathrm{H}_{2}$ yang penulis ajukan dapat diterima, hal ini menunjukkan bahwa produk berpengaruh positif dan siginifikan terhadap minat beli pada PT. Asuransi Jiwa Recapital di Jakarta.

\section{Pengaruh Promosi dan Produk Secara Simultan Terhadap Minat beli Pada PT. Asuransi Jiwa Recapital di Jakarta.}

Dari hasil analisis statistik, diperoleh persamaan model regresi adalah $\mathrm{Y}=3,930+$ $0,460 \mathrm{X}_{1}+0,441 \mathrm{X}_{2}$. Konstansta memiliki nilai positif sehingga apabila promosi dan produk mengalami kenaikan, maka minat beli juga akan meningkat.

Koefisien korelasi antara promosi dan produk secara simultan terhadap minat beli adalah sebesar 0,601. Dengan demikian dapat dikatakan bahwa ketiga variabel memiliki hubungan yang positif sebesar 0,601 dengan tingkat hubungan atau pengaruh kuat.

Nilai koefisien determinasi diperoleh sebesar 0,361, data tersebut mengindikasikan bahwa variabel promosi dan produk secara simultan memberikan kontribusi pengaruh sebesar $36,1 \%$ terhadap minat beli pada PT. Asuransi Jiwa Recapital di Jakarta.

Uji hipotesis diperoleh nilai $\mathrm{F}_{\text {hitung }}>\mathrm{F}_{\text {tabel }}$ atau $(27,400>2,700)$ dan $\mathrm{F}$ signifikansi $<0,05$ atau $(0,000<0,05)$. Dengan demikian hipotesis $\mathrm{H}_{3}$ yang penulis ajukan dapat diterima, hal ini menunjukkan bahwa promosi dan produk secara simultan berpengaruh positif dan siginifikan terhadap minat beli pada PT. Asuransi Jiwa Recapital di Jakarta.

\section{KESIMPULAN, IMPLIKASI, DAN SARAN Kesimpulan}

Setelah penulis melakukan penelitian dan analisis mengenai pengaruh promosi dan produk terhadap minat beli pada PT. Asuransi Jiwa Recapital di Jakarta, seperti yang telah dipaparkan pada bab-bab sebelumnya, maka 
penulis dapat menarik kesimpulan sebagai berikut:

1. Promosi berpengaruh positif dan signifikan terhadap minat beli pada PT. Asuransi Jiwa Recapital di Jakarta. Hal ini dapat dilihat dari Nilai $\mathrm{t}_{\text {hitung }}>\mathrm{t}_{\text {tabel }}(5,182>$ $1,984)$ dan signifikansi $t<0,05$ atau $(0,000$ $<0,05)$ promosi mempunyai korelasi positif dengan minat beli sebesar 0,639. Promosi mempunyai kontribusi pengaruh sebesar 21,5\% terhadap minat beli. Model regresi sederhana yang diperoleh adalah $\mathrm{Y}$ $=14,160+0,584 \mathrm{X} 1$ yang diartikan apabila promosi yang tinggi akan meningkatkan minat beli pada PT. Asuransi Jiwa Recapital di Jakarta.

2. Produk berpengaruh positif dan siginifikan terhadap minat beli pada PT. Asuransi Jiwa Recapital di Jakarta. Hal ini dapat dilihat dari Nilai $\mathrm{t}_{\text {hitung }}>\mathrm{t}_{\text {tabel }}$ atau $(5,405>1,984)$ dan signifikansi $t<0,05$ atau $(0,000<$ $0,05)$ produk mempunyai korelasi positif dengan minat beli sebesar 0,468. Produk mempunyai kontribusi pengaruh sebesar 23,6\% terhadap minat beli. Model regresi sederhana yang diperoleh adalah $\mathrm{Y}=14,771$ $+0,543 \mathrm{X} 2$ yang diartikan apabila produk meningkat maka maka akan meningkatkan minat beli pada PT. Asuransi Jiwa Recapital di Jakarta.

3. Promosi dan produk secara simultan berpengaruh positif dan siginifikan terhadap minat beli pada PT. Asuransi Jiwa Recapital di Jakarta. Hal ini dapat dilihat dari Nilai $\mathrm{F}_{\text {hitung }}>\mathrm{F}_{\text {tabel }}$ atau $(27,400>2,700)$ dan F signifikansi $<0,05$ atau $(0,000<$ 0,05). Promosi dan produk secara simultan mempunyai kontribusi (R2) sebesar 36,1\% terhadap minat beli pada PT. Asuransi Jiwa Recapital di Jakarta, selebihnya sebesar 63,9\% dipengaruhi oleh variabel lain yang tidak diteliti, misalnya kualitas produk, pelayanan, promosi dan lain-lain. Model regresi berganda yang diperoleh adalah $\mathrm{Y}=$ $3,930+0,460 \mathrm{X} 1+0,441 \mathrm{X} 2$ yang diartikan apabila promosi dan produk mengalami peningkatan, maka minat beli juga akan meningkat.

\section{Implikasi}

Dari hasil kesimpulan diatas, penelitian ini memiliki implikasi sebagai berikut :
1. Agar tingkat minat beli pada PT. Asuransi Jiwa Recapital di Jakarta tetap tinggi maka hendaknya variabel promosi harus diperhatikan dan ditingkatkan oleh pihak perusahaan, indikator-indikator yang ada dalam promosi harus dipahami dan dijalankan oleh semua karyawan perusahaan, sehingga produk dan layanan perusahaan dapat dengan mudah diinformasikan ke pelanggan dan akses informasi dibuka dengan lebih luas lagi.

2. Agar tingkat minat beli pada PT. Asuransi Jiwa Recapital di Jakarta tetap tinggi maka hendaknya variabel produk harus diperhatikan dan ditingkatkan oleh pihak perusahaan, indikator-indikator yang ada dalam produk harus dipahami dan dijalankan oleh semua karyawan perusahaan. Produk dan layanan dengan berbagai kemudahan penanganan akan memudahkan pelanggan dalam memilih produk yang sesuai dengan kebutuhannya.

3. Agar tingkat minat beli pada PT. Asuransi Jiwa Recapital di Jakarta tetap tinggi maka hendaknya variabel dan indikator-indikator promosi dan produk secara bersamasama dan terintegrasi harus diperhatikan dan ditingkatkan dan dipahami oleh pihak Perusahaan, guna mendukung terciptanya proses pembelian pelanggan yang berkelanjutan.

\section{Saran}

Berdasarkan kesimpulan di atas, maka penulis mengajukan beberapa saran yang diharapkan dapat bermanfaat bagi PT. Asuransi Jiwa Recapital. Adapun saran tersebut adalah sebagai berikut:

1. Pengaruh promosi terhadap minat beli sebesar 21,5\%, untuk lebih baik lagi perusahaan perlu memperbaiki cara melakukan promosi dan media yang gunakan dalam penyampaian pesan sehingga dapat memberikan informasi yang tepat serta penjelasan yang meyakinkan konsumen, dengan demikian kepercayaan pelanggan merupakan prioritas yang utama.

2. Pengaruh produk terhadap minat beli sebesar 23,6\%, untuk lebih baik lagi perusahaan harus meningkatkan kualitas produk jasa yang memiliki keunggulan dari produk-produk yang lain baik dari segi 
kualitas, manfaat, layanan, dan garansi serta, dan rasa agar dapat menarik minat konsumen untuk membeli produk jasa perusahaan.

3. Berdasarkan hasil penelitian bahwa kontribusi pengaruh variabel bebas terhadap variabel terikat adalah sebesar $36,1 \%$, nilai ini masih bisa ditingkatkan dengan secara perusahaan harus mampu menganalisis kebutuhan pelanggan dengan meningkatkan varian produk layanan dan kondisi masing-masing variabel bebas harus ditingkatkan secara signifikan. Oleh karenanya disarankan kepada penelitian berikutnya agar melakukan penelitian yang relevan dengan cara memperbaiki indikator yang masih tidak baik atau dengan menambah indikator pertanyaan dan jumlah responden penelitian sehingga akan dapat lebih diketahui variabel yang paling memberikan kontribusi positif bagi perusahaan.

\section{DAFTAR PUSTAKA}

Algifari (2010), "Analisis Regresi", Yogyakarta, 2010.

Alma, Buchori (2011). "Manajemen Pemasaran \& Pemasaran Jasa”, CV. Alfabetha, Bandung.

Arikunto, Suharsimi (2011). "Prosedur Penelitian Suatu Pendekatan Praktek", PT. Rineka Cipta, Jakarta.

Assauri, Sofian (2010). "Manajemen Produksi Dan Operasi“, LPFE Universitas Indonesia, Jakarta.

Chandra, Gregorius (2011). "Strategi Dan Program Pemasaran", Andi Offset, Yogyakarta.

G.R. Terry, \& Rue, Leslie W. Rue, (2010), "Dasardasar Manajemen”, Bumi Aksara. Jakarta.

Ghozali, Imam (2013). Aplikasi Analisis Multivariate dengan Program SPSS", Edisi Kelima, Badan Penerbit Undip, Semarang.

Handi Chandra (2011). Prinsip Kepuasan Nasabah", Cetakan kelima, Elex Media Komputindo, Jakarta.

Hasan, Ali (2009). Marketing". Media Utama, Yogyakarta.

Hasibuan (2016), "Manajemen Sumber Daya Manusia", Haji Masagung. Jakarta.

Istijianto (2009). "Aplikasi Praktis Riset
Pemasaran", Gramedia Pustaka Utama, Jakarta.

Keller dan Amstrong. (2014), "Prinsip-prinsip Pemasaran”, Edisi Kedua Belas. Jilid Satu. Erlangga. Jakarta.

Kotler, (2016), "Manajemen Pemasaran", Edisi Keempat belas, PT. Indeks, Jakarta.

Kotler, dan Keller, (2016), "Manajemen Pemasaran", PT Macaman Jaya Cemerlang. Jakarta.

Laksana, Fajar (2013). "Manajemen Pemasaran", Edisi Pertama, Graha Ilmu, Yogyakarta.

Safroni, Ladzi (2012). "Manajemen dan Reformasi Pelayanan Publik dalam Konteks Birokrasi Indonesia", Aditya Media Publishing, Surabaya.

Saladin, Djaslim (2012). "Manajemen Pemasaran", Linda Karya, Bandung

Sarwono, Jonathan. 2012. "Metode Penelitian Kuantitatif Dan Kualitatif". Graha Ilmu. Yogyakarta.

Simamora, Bilson (2012). "Panduan Perilaku Konsumen”, Penerbit PT. Gramedia Pustaka Utama, Jakarta.

Sugiyono (2014) "Metode Penelitian Kuantitatif Kualitatif dan $R$ \& $D$ ”, Penerbit CV. Alfabeta, Bandung.

Swastha, Bashu dan T. Handoko (2010). "Manajemen Pemasaran Moderen", BPFE, Yogyakarta.

Syofian Siregar (2010). "Statistika Deskriptif Untuk Penelitian", PT Raja Grafindo Persada, Jakarta.

Tjiptono, Fandy (2011). "Pemasaran Jasa", Edisi Pertama, Bayu Media Publishing, Malang.

Tjiptono, Fandy dan Gregorius Chandra. 2012. "Serivce Quality and Satisfiation". Edisi tiga. Andi. Jakarta.

Umar, Husen (2013). "Riset Pemasaran Dan Perilaku Pelanggan”. PT. Gramedia Pustaka Utama. Jakarta.

Usmara (2012), "Strategi Baru Manajemen Pemasaran", Amoro book, Yogyakarta.

Wiliam J. Stanton (2010). "Prinsip-Prinsip Pemasaran”, Edisi ketujuh, Erlangga, Jakarta. 